\title{
Relationship between the Sensory Evaluation of Stiffness and Bending Stiffness Distribution Curve of the Fiber Components of a Hair Tress
}

\author{
Ueda Seiko $^{\mathrm{a}, *}$, Kuwabara Satomi ${ }^{\mathrm{b}}$, JoKo Kyohei ${ }^{\mathrm{b}}$ \\ ${ }^{a}$ R\&D, Health \& Beauty Company, Sunstar Group, 5-30-1, Kamihamuro, Takatsuki, Osaka 569-1044, Japan \\ ${ }^{\mathrm{b}}$ School of Life Studies, Sugiyama Jogakuen University, 17-3 Hoshigaoka-motomachi, Chikusa-ku, Nagoya, Aichi, 464-8662, Japan
}

Received 27 September 2016; accepted for publication 9 February 2017

\begin{abstract}
We performed a sensory evaluation of the stiffness of aged hair and damaged hair, and examined the relationship between the obtained sensory evaluation and the bending stiffness distribution curve of the whole hair tress. We used a mixture of gray and black hair as an aged hair tress, and of bleached and permed hair as damaged hair tresses. The results indicated a difference in sensory evaluation of stiffness between the gray and black hair tresses and a difference in the high-rigidity range $(85 \%-100 \%)$ in the bending stiffness distribution curve. A difference was observed in sensory evaluation of stiffness between the different damaged hair tresses. However, chemical treatments resulted in changes in both the low- and high-rigidity regions in the bending stiffness distribution curve. We attempted to find the area of highest correlation between the distribution curve and the sensory evaluation. The distribution curve was divided into several areas and the stiffness average was calculated for each area. We then calculated the correlation coefficient with the sensory evaluation. The results indicated that the area with the top $10 \%-15 \%$ stiffness of the distribution curve was most closely correlated to the sensory evaluation.
\end{abstract}

Key Words : Hair, Sensory evaluation, Bending stiffness, Correlation coefficient,

\author{
毛束のハリコシ官能評価と構成毛髪の \\ 曲げ剛性分布曲線との関係 \\ 上田誓子 ${ }^{\mathrm{a}, *}$, 桑原里実 ${ }^{\mathrm{b}}$, 上甲恭平 ${ }^{\mathrm{b}}$ \\ a サンスターグループ ヘルス\&ビューティーカンパニー 研究開発部, \\ ${ }^{\mathrm{b}}$ 椙山女学園大学 生活科学部 生活環境デザイン学科
}

\section{1. 緒 言}

加齢に伴い「毛髪のハリ・コシがなくなってきた」という 悩みが生じる [1]. 渡辺らは 35 才から 59 才の女性 351 名を 対象にした髪の悩みに関する調査において，「髪にハリ・コ シがない」という悩みは「白髪」についで多く, $33 \%$ も安 性が悩んでいることを報告している $[2]$. 毛髪の「ハリ・コ シ感」はその「硬さ」や「柔らかさ」と同様に, 太さやクセ の程度が異なる様々な毛髪の集合体である毛束の特性による ものと考えられる。その中で「柔らかさ」は，「指を滑らせ た時などの滑らかさ」,「指の通りやすさ」や「握ったり，曲
げたりした時の, 跳ね返りや抵抗感のなさ」で判断しており, 毛束の硬さ・柔らかさには, 毛髪の太さ, 滑らかさ以外に毛 髪の揃い指数も感じる要因となっていることは明らかである [3]. 一方,「ハリ・コシ感」については, 毛髪密度や, 太さ および曲げ剛性が関係していると考えられているが [2], もっ とも基本的な物性因子の一つには毛髪 1 本の曲け硬さ (剛性) が挙げられており，古川 [4]は毛髪のハリコシ感を評価する 方法として,毛髪コシ感テスター (KES-FB2-S-DC・カトーテッ ク株式会社) に毛髪 50 本を $5 \mathrm{~cm}$ 間に等間隔で並行に取り付 け，曲げ剛性Bを測定する方法を紹介している。しかしなが ら曲げ剛性Bが大きければ毛髪がかたくコシがあると解釈さ

*連絡先：サンスターグループ ヘルス\&ビューティーカンパニー＼cjkstart研究開発部 569-1044 大阪府高槻市上土室 5-30-1 E-mail : seiko.ueda@jp.sunstar.com, Tel : +81-72-694-7788, Fax : +81-72-695-0766 
れる傾向にあるものの, 官能評価で感じられる「ハリ・コシ感」 とは必ずしも一致しないことがあるとも報告している。よっ て, ハリコシ感とより相関性の高い評価方法が求められてい るといえる

我々は，これまでに髪の毛の柔らかさ，ハリコシ感の指標 となり得る毛束としての曲け剛性に着目し，前報において毛 髪 1 本 1 本の曲げ硬さ（剛性）を測定し，曲げ剛性 (B)，断 面積 $(\mathrm{S})$, 断面二次モーメント $(\mathrm{I})$, ヤング率 $(\mathrm{E})$ などの物 性值の解析を行い，それぞれの物性值を昇順に並べてプロッ 卜した分布曲線を用いることで毛束間の特性の違いを読み取 ることができることを報告した $[5]$ ，そこで，本研究では毛 束の柔らかさ, ハリコシ感に対する官能評価と前報の方法に 準じて求めた毛束の曲げ物性分布曲線のひとつである曲げ剛 性分布曲線との相関に関する知見を得ることを目的とした

髪の毛のハリコシ感は, 前述のとおり年齢とともに低下す ることが報告されている $[1,2]$. 加齢により低下したハリコ シ感を評価するためには，同一人物の若年齢時の毛髪と加齢 時の毛髪を用いることが理想的であるが, 両方の毛髪の入手 は非常に困難である。そこで，加齢に伴い白髪が増えること に着目し，白髪の増加が毛髪全体のハリコシ感の低下に何ら かの影響を与えているのではないかと考え, 同一人物の白髪 混合毛束を入手し, 黒髪と白髪に分け, 同重量の毛束を作成 し，ハリコシの官能評価とそれぞれの毛束の曲げ剛性分布曲 線との相関関係について検討した。 次に, ハリコシ感は日常 のへアケアによる損傷によっても変化することが報告されて いる [6-9]ことから, 日常的に行われているブリーチおよび パーマ処理を施した毛髪についてもハリコシの官能評価と 曲げ剛性分布曲線との関係を検討した。また，日常のシャン プー・トリートメント等のヘアケアでの損傷は，主に非ケラ チン組織である細胞膜複合体 $(\mathrm{CMC})$ やエンドクチクルな どであることが知られている $[10]$ ，中でも CMC は弾性的性 質をもち, キューティクル細胞やコルテックス細胞同士を接 着することで，繊維の物理的，化学的特性に影響を及ぼすこ とが報告されている [11]，この CMC は，有機溶媒等で容易 に改質されることが知られており，Leeder らの濃ギ酸処理に よってミクロフィブリルーマトリックスは影響を受けていな いが, CMC は変化しているとする羊毛繊維の透過電子顕微 鏡（TEM）観察での報告 [12] からはじまり，多くの研究者 によって確認され，著者の一人も毛髪において同様の現象を 観察し報告している [13]，そこで $\mathrm{CMC}$ を優先的に改質させ たギ酸処理毛髪を $\mathrm{CMC}$ 損傷モデル毛髪と位置づけ，ギ酸処 理毛髪のハリコシの官能評価と曲げ剛性分布曲線との関係に ついても検討することにした。

\section{2. 実験方法}

\section{1 実験試料}

毛髪試料には，中国人女性の同一人白髪混合毛髪 $(20 \mathrm{~cm})$ と 同一人黒髪 $(60 \mathrm{~cm}$ ：共にビューラックス社製）を用いた。白 髪混合毛髪は各採取者 $(\mathrm{A}-\mathrm{C})$ 毎に白髪と黒髪に全て分けた後,
それぞれから同一重量（約 $2.1 \mathrm{~g} ）$ の白髪毛束と黒髪毛束を作 成した。同一人黒髪は根元に近い側から長さ $25 \mathrm{~cm}$ に切断し, 重量約 $3.2 \mathrm{~g}$ ，毛髪約 5000 本の毛束を複数本作成した，作成し た毛束は流水で充分に濡らした後，1\%ラウリル硫酸ナトリウ 厶水溶液を $10 \mathrm{~g}$ 塗布し, 20 回櫛通して洗浄した後, 流水中で 櫛通ししながら充分にすすぎ， $55^{\circ} \mathrm{C}$ の乾燥機で乾燥させた。

\section{2 改質モデル毛束の作成方法}

\subsection{1 ブリーチ処理毛束}

ブリーチ処理剂には，ブリーチパウダー $4 \mathrm{~g}$ を秤取し $30 \%$ 過酸化水素水 $5 \mathrm{ml}$ を蒸留水で $20 \mathrm{ml}$ に希釈した過酸化水素 水をブリーチパウダーに加えてよく混ぜ合わせたものを用い た。ブリーチ処理は，白板にラップを敷き，その上に同一人 黒髪で作成した毛束を置き，ブリーチ処理剤を流し入れた後 ラップを畳み，処理剤を十分に毛束になじませ，室温にて 30 分間放置した。処理後, 水洗し, 自然乾燥させた。この操作 を 1 〜 回行った毛束を用意した.

\section{2 .2 パーマ処理毛束}

パーマ処理 I 剂（還元処理溶液）には $5 \%$ チオグリコール 酸水溶液を作成し，アンモニア水溶液を用いて $\mathrm{pH} 9.0$ に調 整したものを，パーマ処理 II剂（酸化処理溶液）には $7.5 \%$ ブロム酸水溶液を作成し，リン酸水素二ナトリウム，リン酸 二水素ナトリウムを用いて $\mathrm{pH} 6.0$ に調整したものを用いた. パーマ処理は，まず同一人黒髪で作成した毛束を処理 I 剂 $100 \mathrm{ml}$ に $35{ }^{\circ} \mathrm{C}$ で 10 分間浸漬させ, その後水洗を 2 分行い, 次に処理 II剂 $100 \mathrm{ml}$ に $35^{\circ} \mathrm{C}, 10$ 分浸漬後, 水洗を 2 分行い, 自然乾燥させることで行った。この操作を 1 〜 回行った毛 束を用意した

\subsection{3 ブリーチ/パーマ処理毛束}

同一人黒髪で作成した毛束を 2.2 .1 に記載のブリーチ処理 を行った後, 2.2.2 記載のパーマ処理を行った。この操作を 1 〜 2 回繰り返した毛束を用意した。

\subsection{4 ギ酸処理毛束}

同一人黒髪で作成した毛束を濃ギ酸（98～100\%，JIS 試 薬特級, ナカライテスク製） $100 \mathrm{ml}$ に 15 分間，室温で浸漬 した. 処理後, 流水で十分に水洗した後, $55^{\circ} \mathrm{C}$ の乾燥機で 1 時間乾燥させた。

\section{3 官能評価}

\subsection{1 白髮と黒髮毛束の官能評価}

まず, 2.1 実験試料に記載した同一人物 (A) の黒髪毛束お 
よび白髪毛束についてハリコシの官能評価を実施した。評価 は通常の室温下 $\left(15^{\circ} \mathrm{C}-25^{\circ} \mathrm{C}\right)$, 湿度 $(60 \% \mathrm{RH}$ 以下)で行った。 各毛束の色が視認できないように黒色のビニル袋を被せ, ビ ニル袋の下に手を入れてどちらが柔らかいかを 30 名の女性 に回答してもらった。柔らかさに差が無い場合や，わからな い場合は，そのように回答してもらった。次にハリコシ感に ついても同様の方法で, 60 名の女性にどちらがハリコシがあ るか回答してもらった。 さらに, 同一人物 $(\mathrm{B}, \mathrm{C})$ の白髪毛 束と黒髪毛束について, ハリコシ感の差がどの程度かを確認 するため同様の方法で, 15 名の女性にそれぞれの毛束のハリ コシ感の程度を 5 段階 $(1:$ ハリコシ無し $\Leftrightarrow 5$ :ハリコシ有り $)$ で回答してもらった。

\section{3 .2 改質モデル毛束の官能評価}

2.2 改質モデル毛束の作成方法に記載した各種改質モデル 毛束と末処理毛束の計 10 束のハリコシ感について, 20 代〜 40 代女性 15 名〜 16 名で官能評価を実施した。一度に評価 する毛束数が多いと, 官能評価時の集中力が低下する懸念か ら, 1 回当りの評価に用いる毛束は 7 束とし, Table 1 に示す とおり振り分けた.

Table 1 List of hair tresses used for each sensory evaluation tests.

\begin{tabular}{lcc}
\hline treatment & $\begin{array}{c}\text { 1st sensory } \\
\text { evaluation test }\end{array}$ & $\begin{array}{c}\text { 2nd sensory } \\
\text { evaluation test }\end{array}$ \\
\hline untreated & 0 & 0 \\
\hline single Bleach & 0 & - \\
double Bleach & 0 & - \\
triple Bleach & 0 & 0 \\
\hline single Perm & - & 0 \\
double Perm & - & 0 \\
triple Perm & - & 0 \\
\hline single Bleach and Perm & 0 & - \\
double Bleach and Perm & 0 & 0 \\
\hline Formic acid & 0 & 0 \\
\hline
\end{tabular}

それぞれの毛束群の官能評価は, 通常の会議室条件下 (18 ${ }^{\circ} \mathrm{C}-25^{\circ} \mathrm{C}$, 湿度 $60 \% \mathrm{RH}$ 以下）で実施した。 温度・湿度の厳 密なコントロールができなかったことから, 温度および湿度 変化による毛束の感触の大幅な変化を避けるため, 1 回の官 能評価はその日のうちに連続して全員に実施, 完了させた. さらに2 回の官能評価の再現性を確認する目的で未処理毛 束, ギ酸処理毛束, ブリーチ 3 回処理毛束, ブリーチ/パー マ処理を 2 回繰り返した毛束を毎回評価に加えた. 毛束 7 束 にはあらかじめ異なるアルファベットを表記しておき，ハリ コシ感を 5 段階（1．無しヒハリコシ $\rightarrow 5$ ，有り）で表記し た評価用紙に，それぞれの毛束のハリコシ感ごとにアルファ ベットを記入してもらった。 なお, 毛髪のハリコシ感につい ては現在のところ明確な定義はないが, 多くの女性が認識し ている感覚であることから, 評価時には「自らが思う毛髪の ハリコシ感」で評価するよう伝え, 個室にて一人ずつ評価さ せた。

\section{4 毛髮の曲げ剛性測定方法}

各毛束を構成する毛髪の曲げ剛性の測定は, 前報 [5] で報 告した一本曲げ試験機 (KES-FB2-SH・カトーテック株式会 社 ）を用いて行った。試験機に毛髪の測定部を取り付け, 曲 げ応力を曲率 $(\mathrm{K})-2.5 \sim+2.5\left(\mathrm{~cm}^{-1}\right)$ の範囲で $0.4\left(\mathrm{~cm}^{-1} \cdot \mathrm{s}^{-1}\right)$ の 変化速度で計測し, 得られた曲げ応力ー曲率曲線での $\mathrm{K}: 0.5$ $\sim 1.5 \mathrm{~cm}^{-1}$ および-0.5 - $1.5 \mathrm{~cm}^{-1}$ 間における曲線の傾斜の平 均を曲げ剛性 B 值として算出した.

\subsection{1 白髮と黒髪の曲げ剛性測定方法}

同一人物 $(A)$ の白髪と黒髪の毛束からそれぞれ 50 本の毛 髪について, 1 本につき 3 箇所（根元より $5 \mathrm{~cm}, 10 \mathrm{~cm}, 15$ $\mathrm{cm}$ の地点)の曲げ剛性 B 值を測定した. さらに, 別人物 (E-J) から入手した白髪と黒髪についても, それぞれ 100 本の毛髪 について, 毛髪 1 本につき 1 箇所ずつ, 毛髪の中心の曲げ剛 性B 值を測定した.

\subsection{2 改質モデル毛束の曲げ剛性測定方法}

各種改質モデル毛束からそれぞれ 200 本の毛髪について, 毛髪 1 本につき 1 箇所ずつ, 毛髪の中心の曲げ剛性 B 值を測 定した。

\section{3. 結果と考察}

\section{1 ハリコシ感に及ぼす白髮の影響}

\subsection{1 白髮・黒髮毛束のハリコシ官能評価}

Fig. 1 に同一人物 (A) の白髪毛束と黒髮毛束のハリコシの 官能評価結果を示す。「どちらが柔らかいか」との問いに対 して 30 名中 $60 \%$ の女性が白髪毛束の方が柔らかいと評価し た。一方，「どちらがハリコシがあるか」との問いに対して は 60 名中 $56 \%$ の女性が黒髪毛束の方がハリコシがあると評 価した。よって，一部の女性で「(ハリコシがなにか) わか らない」との回答があったものの，ハリコシの感覚は $93 \%$

\section{Which is softer?}

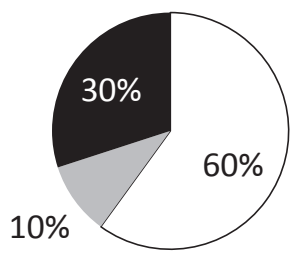

$\square$ Gray hair $\quad$ same

- black hair

\section{Which is stiffer?}

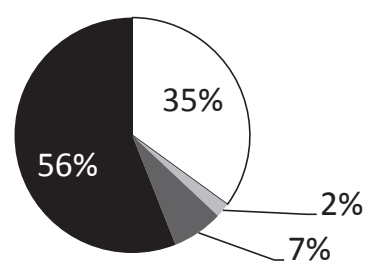

$\square$ Gray hair $\quad \square$ same - Unanswerable Black hair
Fig. 1 Sensory evaluation about softness and stiffness of person A's gray hair and black hair tress. 
の女性が認識できる感覚であり，その評価結果は「柔らかさ」 の評価結果とほぼ逆の結果となることがわかった。

\section{1 .2 毛束構成毛髮の曲げ剛性分布曲線}

次に，同一人物 (A) の白髪と黒髪毛束からそれぞれ毛髪を 50 本ずつ抜き出し， 1 本につき 3 箇所測定して得られた計 150 個の曲け剛性 B 值を低值より高值にかけて昇順で並べた 「曲げ剛性分布曲線」を Fig. 2 に示した。

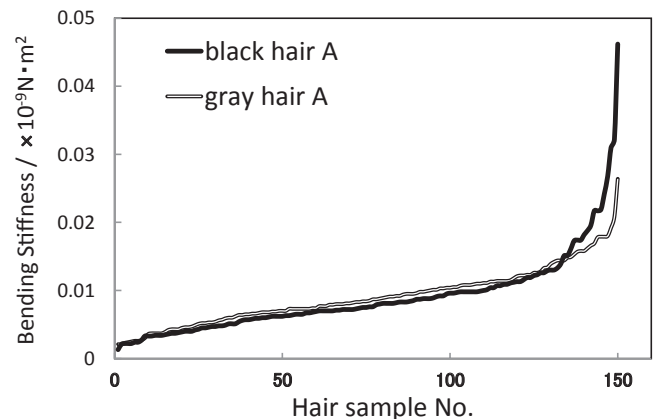

Fig. 2 Bending stiffness distribution curves of person A's black hair and gray hair.

Fig. 2 において曲げ剛性が低值の領域（サンプル No.137 ま で，全体の $86.3 \%$ の毛髪：低剛性域）では, 白髪の方が黒 髪よりわずかに高い值を示すが，曲げ剛性が高值の領域（サ ンプル No.137 以上，全体の $13.3 \%$ の毛髪：高剛性域）では, 明らかに黒髪の方が高い曲け剛性值を示し，白髪の曲げ剛性 值と明らかに差違が認められる。

緒言で述べたように，毛束のハリコシ感が毛束を構成する 毛髪の曲げ剛性に左右されるのであれば, これらの分布曲線 の違いが反映しているはずであり, 官能評価では白髪の方が ハリコシがない, と評価する声が多かったことは, 高剛性域 における黒髪と白髪の曲げ剛性值の差が影響を与えていると 考えられる。つまり，全体の $13.3 \%$ に過ぎない高剛性域の 毛髪が毛束全体のハリコシ感に強く影響を与えており，剛性 值の低い大半の毛髪はハリコシ感には影響を与えていないこ とが示唆される。

そこで，この点を確認することを目的として，剛性值の高 い毛髪の含有率を変化させた毛束試料を作製し, その官能評 価を行った

\section{2 高剛性毛髪含有率とハリコシの官能評価との 関係}

\subsection{1基準となる同一人毛髪の曲げ剛性分布曲線 の作成}

高剛性毛髪の含有率を変化させた毛束試料を作製するため に，同一人物の黒髪で作成した毛束を複数本用意した。これ
らの毛束に対して，高剛性域の毛髪を段階的に混入し，毛束 全体のハリコシ感に変化が生じるかを確認することにした． このとき，その毛束における高剛性值を把握するため，毛束 試料から 200 本の曲げ剛性 B 值を毛髪 1 本につき 1 箇所ず つ測定し，曲げ剛性分布曲線を得た。この分布曲線に，3.1.2 で設定した高剛性域である上位 $13.3 \%$ を当て, 曲げ剛性值 が 174 番目の毛髪の曲げ剛性 B 值を確認したところ 0.0139 で あった。よって曲げ剛性 B 值が 0.0140 以上が, この黒髪毛 束試料の高剛性毛髪であると設定した。

\subsection{2 高剛性毛髪の含有率の操作と官能評価}

曲げ剛性 B 值が 0.0140 以上である高剛性毛髪を 500 本用 意し, 毛束試料の毛髪 500 本と入れ替えることで, 高剛性毛 髪を約 $10 \%$ 増加した毛束を作成した。 この毛束と, 未処理 毛束と一対でハリコシの官能評価を 20 代〜 40 代の女性 15 名で実施した。その結果，Fig. 3 に示したように，高剛性毛 髪を $10 \%$ 増加させた毛束では, 有意にハリコシの官能評価 が高かった。さらに, 高剛性毛髪の混入数をそれぞれ 250 本, 150 本と混入させて，高剛性毛髪の混入率をそれぞれ約 $5 \%$, 約 $3 \%$ 増加させた毛束を同様に作成し，未処理毛束と官能試 験を実施した。その結果, 高剛性毛髪の混入割合に応じて毛 束のハリコシが増加する傾向が見られた。 よって, 毛束全体 のハリコシ感には曲げ剛性 B 值が高い毛髪の剛性值が強く影 響しているものと考えられた。
Which is stiffer? $(\mathrm{N}=15)$

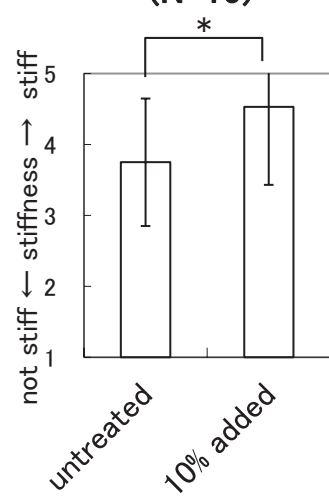

Which is stiffer? $(\mathrm{N}=15)$

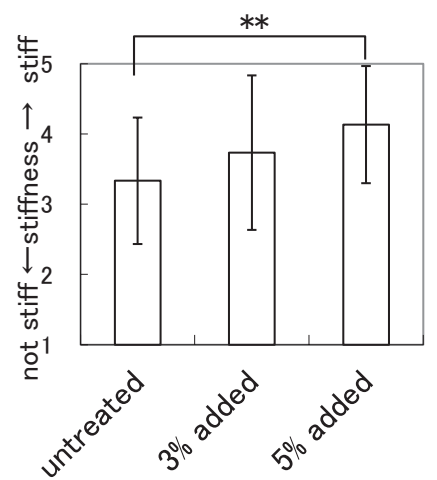

Fig. 3 Sensory evaluation of hair tresses some of which added high stiffness hairs.

\section{3 白髮毛のハリコシ}

我々は, 白髪がつねに黒髪よりもハリコシが低いことが加 齢による毛髪のハリコシの低下の原因であるのかを確認する ため, 別の人物 (B， C) の白髪混合毛髪より白髪と黒髪の毛 束を作成し、ハリコシの官能評価を実施した (Fig. 4)。さらに, 別の人物 6 名 $(\mathrm{E}-\mathrm{J})$ の白髪と黒髪 100 本ずつの曲げ剛性值か 
ら曲げ剛性分布曲線を作成した (Fig. 5)。まず，Fig. 4 に示す ように，人物 B では逆に白髪の方がハリコシが高かったこと から，白髪は必ずしも黒髪よりもハリコシが低下しているわ けではないことを確認した。同様に，Fig. 5 に示したE-Jの 白髪と黒髪の曲げ剛性分布曲線においても, 白髪と黒髪の曲 線が完全に重なっている毛髪も見られ，高剛性域において白 髪の曲線が必ずしも黒髪より低いというわけではなかった。

以上のように，加齢とともに増加する白髪とハリコシの低 下との間に何らかの関係があるか，との仮説のもとに同一人 物の白髪毛束と黒髪毛束間の官能評価およびそれぞれの曲げ 剛性分布曲線の比較を行ったが, 白髪が必ずしもハリコシ感 を決定する要因ではないと結論できた。しかしながら， 3.2 .2 項で示したように, 高剛性の毛髪を $10 \%$ 混入させると, 官 能評価では有意にハリコシがあると評価されたことから，毛 束を構成する曲げ剛性值の高い毛髪がハリコシ感に影響をお よぼしていることは十分に考えられる。
Which is stiffer? $(\mathrm{N}=15)$
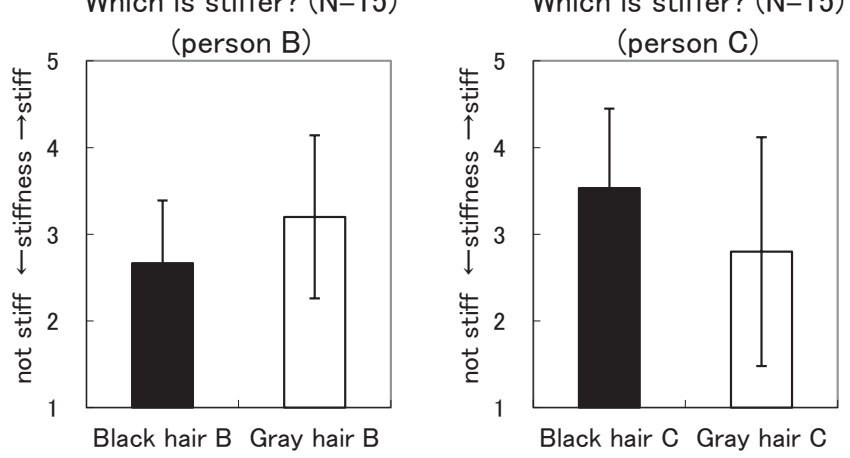

Fig. 4 Sensory evaluation of each person's gray hair and black hair tresses.
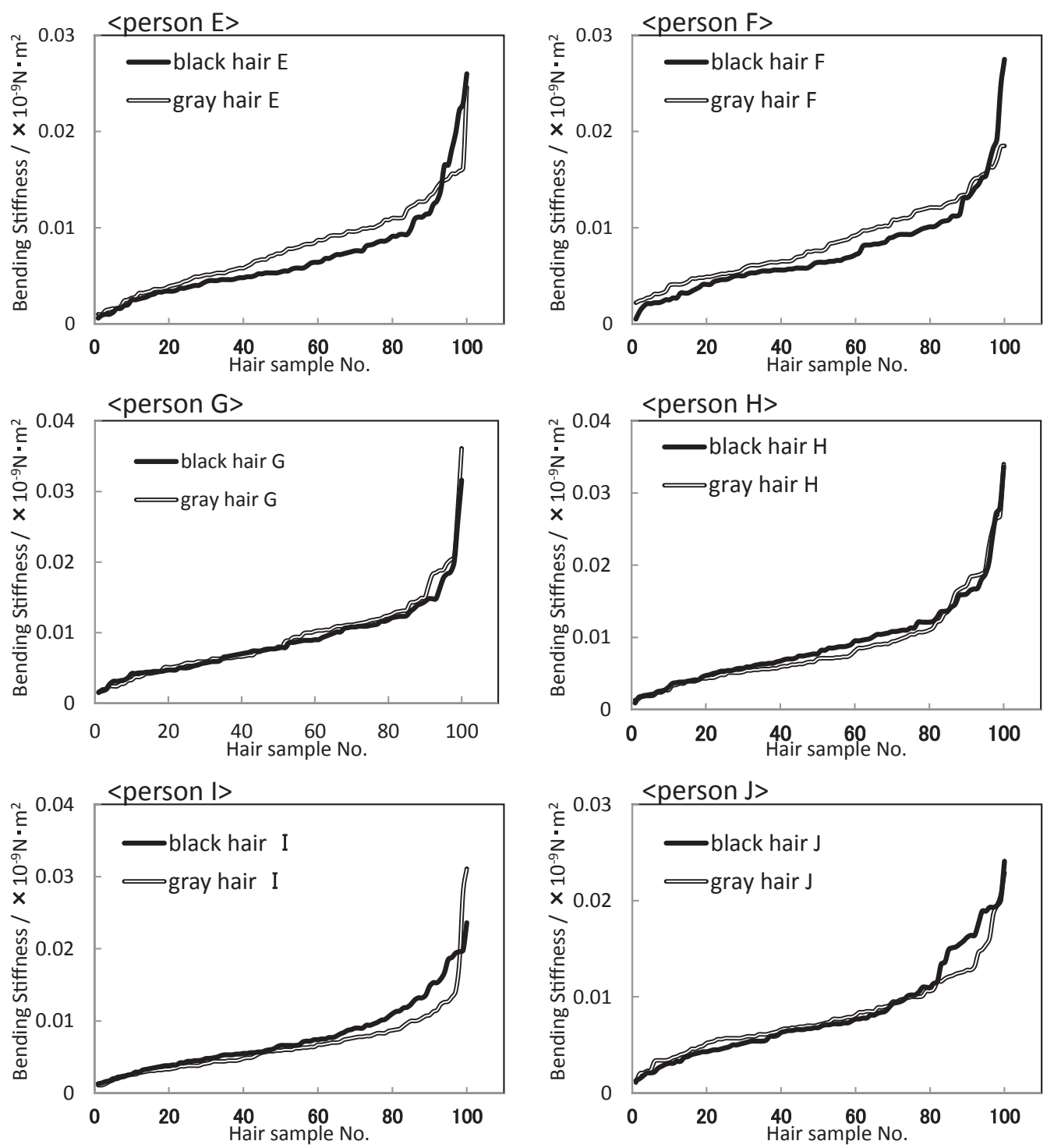

Fig. 5 Bending stiffness distribution curves of each person's black hair and gray hair. 


\section{4 同一人黒髮毛束の各種改質処理}

我々は次に，様々な化学処理によって改質させた毛髪の八 リコシ感と, それらの改質毛束に含まれる高剛性毛髪との間 にも同様の関係がみられるかについて検討するため, 2.2 改 質モデル毛束の作成方法で記した各種改質処理を実施した。 ここで，ブリーチ処理およびパーマ処理を 1 回，2回，およ び3 回繰り返した毛束をそれぞれ B1, B2, B3 および P1, P2, P3 と, ブリーチ処理後にパーマ処理を 1 回および 2 回 繰り返した毛束をそれぞれ BP1，BP2 と略記した。さらに, 濃ギ酸処理を施した毛束を formic acid と略記した。

\subsection{1 改質処理毛束のハリコシの官能評価}

各種改質処理毛束と未処理毛束の計 10 束を Table1 に示し たとおり 2 回に振り分け, 20 代〜 40 代女性 15 名〜 16 名で ハリコシの官能評価を実施した結果を Fig. 6 に示す。まず, 官能評価 1 回目と 2 回目で共通する改質処理毛束の未処理毛 束に対するハリコシの官能評価はほぼ同様の傾向を示してい たことから, エラーバーは大きいものの 2 回の官能評価の再 現性は高いものと考えられた。 そこで, これらの結果を比較 すると, 改質処理によるハリコシ感への影響において最も八 リコシが低下した改質処理毛束は, 濃ギ酸処理毛束 (Formic acid）であり。ブリーチ処理毛束（B2）およびパーマ処理毛 束 (P1) は未処理毛束に対してハリコシがやや高いとみなせ るのに対して, ブリーチ処理毛束 (B1，B3), パーマ処理毛 束 $(\mathrm{P} 2, \mathrm{P} 3)$ および. ブリーチとパーマを繰り返した毛髪 $(\mathrm{BP} 1$, BP2) では，未処理毛束とほぼ同等でありハリコシは変化し ないと評価された

ここで得られた官能評価結果については, 一般に温度・湿 度などの環境変化は毛髪の手触り感に影響を与えることが知 られており，評価におよぼす試験環境の影響を考慮する必要 がある，河野ら [14]はブリーチ，ブラッシングおよびパー マの繰り返し処理により損傷させた毛髪に各種のトリートメ
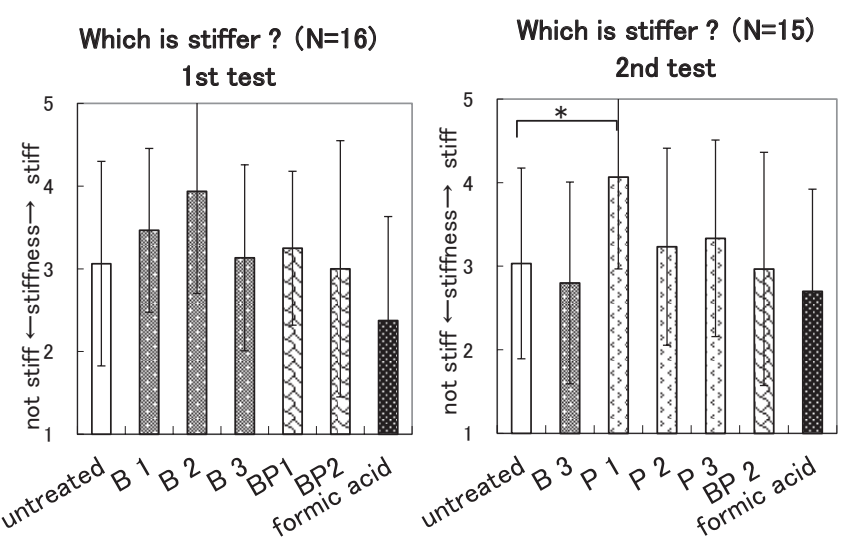

Fig. 6 Sensory evaluation of untreated hair tress and chemical damaged hair tresses.

B1: single Bleach, B2: double Bleach, B3: triple Bleach P1: single Perm, P2: double Perm, P3: triple Perm BP1: single Bleach and Perm, BP2: double Bleach and Perm
ント殽を塗布した毛束を用意し, 温度・湿度などの環境を変 化させた条件で毛髪の物理特性の測定と官能評価を行い, そ れらの相関性を確認した。 その結果, 低温. 低湿状態 $\left(15^{\circ} \mathrm{C}\right.$, $30 \% \mathrm{RH})$ および標準状態 $\left(20^{\circ} \mathrm{C}, 64 \% \mathrm{RH}\right)$ では毛髪のやわら かさと曲げ剛性 B 值との間に高い負の相関が得られたが，高 温・高湿状態 $\left(30{ }^{\circ} \mathrm{C}, 80 \% \mathrm{RH}\right)$ では相関が得られなかったこ とから, トリートメント効果などの微細な差を比較検討する 際は。標準状態または低温・低湿環境下で実施するのが良い としている。 今回我々が実施した官能評価は, 低温・低湿状 態から標準状態で実施したことから, エラーバーは大きかっ たものの微細な感覚の差が再現されているものと考えられ る.

そこで, 得られた改質処理効果と官能評価との関係につい て考察を試みた。まず CMC が優先的に改質されたと考えら れる濃ギ酸処理毛束のハリコシが低下すると評価されたこと は興味深いことである。このことは, 毛束のハリコシ感に対 して構成毛髪の内部構造変化に基づく物理特性変化が関与し ていることを示しており, その構造変化において毛髮全体の わずか数％しか占めていない $\mathrm{CMC}$ の構造変化の寄与が大き いことを示すものである。一方, パーマやブリーチ処理も緎 維内部構造にさまざまな影響をおよぼしている。パーマおよ びブリーチ処理の本質は酸化・還元反応であり, 毛髪構成た んぱく質への反応が化学構造変化を引き起こし, その変化が 高次 (凝集) 構造の変化をもたらしている.こられのことは 古くから検討され多くの研究者によりその成果が報告されて いる [15]. 既に述べたが濃ギ酸処理毛髪では，主に CMC 構 成成分の抽出とそれに伴う構造の乱れが TEMにより観察さ れている. 同様に, パーマやブリーチ処理毛髪の内部構造も TEM 観察やラマン分光分析により調べられている。その結 果, 一般に使用されているパーマ剂であるチオグリコール酸 により 20 分から 40 分間処理することにより，1) キューティ クル細胞の膨潤 [16]，2）コルテックス細胞でのマクロフィ ブリル間マトリックスの弛緩 [17]，3）中間径フィラメント タンパク質 (IF) とフィラメント結合タンパク質 (IFAP) との 規則構造の乱れ [18], 4) CMC およびその周辺組織の構造弛 緩 [18] などが観察されることが報告されている，また，通 常のブリーチ処理毛髪について, 最近, 査型 X 線微分位相顕 微鏡を用いて観察した結果が報告され，ブリーチ処理により キューティクル細胞内の層状の密度分布が消失することが示 された [19]. また, 名和 [20］は原子間力顕微鏡 (AFM) ハー モニックスモードのブリーチ毛髪の断面の弾性率変化を調 ベ，ブリーチ処理によってコルテックス細胞の弾性率が高く なること，その主たる組織成分は IFAP であることを報告し ている

以上の知見に基づけば，本実験で使用したパーマやブリー チ処理毛髪は， $\mathrm{CMC}$ の構造が弛緩しているだけでなく，コ ルテックス細胞内のマクロフィブリル間マトリックスや IF/ IFAP 間の凝集構造も乱していると考えられるものの, 処理 回数にもよるが, コルテックス細胞層の弾性率は低くなって いないと考えられる.よって,ブリーチ処理毛束 (B2) やパー マ処理毛束 (P1) でハリコシが強く感じられたのは, コルテッ 
クス細胞の弾性率向上が関係し, さらなる処理でハリコシ感 が弱くなったのは，CMC 等の非ケラチン組織成分の損傷に 伴う内部歪応力の低下によるものと推察される。これは，八 リコシを感じる触覚が作用反作用の法則に支配され，触るこ とによって毛束を構成する毛髪の形状を変形させ，その変形 の仕方や様子の情報を反作用力として受け取り感じていると 考えられていることに基づく。すなわち，すべての被験者が 同じ方法で毛束を変形させている訳ではないが，少なくとも 毛束を曲げるような変形は含まれており, その際の外力（作 用力）に対して個々の䋊維内部で発生する歪応力（反作用力） を感じ取っていると考えられる。したがって，毛束のハリコ シとして感じ取る情報の一部には間違いなく毛束あるいは毛 髪の曲げ応力が含まれていると考えられたことから，同様に 各改質毛束の曲げ剛性分布曲線を求め, ハリコシ感との関係 を検討することにした。

\section{4 .2 改質処理毛束の曲げ剛性分布曲線}

Fig. 7 は, 改質処理毛束からそれぞれ毛髪 200 本を無作為 に採取し，毛髪 1 本につき 1 箇所ずつ，毛髪の中間部分を測 定し，未処理毛束の曲げ剛性分布曲線と共に示したものであ る。図から明らかなように，それぞれの改質処理毛束は様々
な曲げ剛性分布曲線を示したが，ブリーチ/ パーマ2 回処理 毛束（BP2）を除き，いずれの処理によっても低剛性域および 中剛性域の值が未処理毛束のそれより高くなり, 高剛性域の 值が変わらないか, 低くなった。これらの結果は, 白髪と黒 髪で得られた分布曲線とは明らかに異なっている。単純に構 成毛髪の曲け剛性值の違いがハリコシ感に反映しているので あれば, ブリーチ/パーマ2 回処理毛束 (BP2) では, 明らか に処理毛束の方が曲げ柔らかい毛髪が多くなっており，曲げ 柔らかくなっていると考えられるが，実際のハリコシの官能 評価では未処理と変わらないと判定されている。このことか ら, 少なくとも低剛性および中剛性域の分布の差違はハリコ シ感にはほとんど影響をおよぼしていないと言うことができ る。さらに, 前述したハリコシ感が構成毛髪の曲げ剛性分布 曲線での高剛性域の分布に関係しているとの考えを支持して いるように捉えることができる。

しかしながら，これまでの議論は曲げ剛性值から得られる 情報とハリコシ感との間に何らかの関係があるとする前提に 基づいた議論であり，定性的な議論にとどまっている。そ己 で上述したようにハリコシ感として感じ取る情報の一部が曲 げ剛性分布曲線の中に含まれるとして, 改質処理毛束での官 能評価と曲げ剛性分布曲線に含まれる情報との関係をより定 量的に解析するため相関因子の検出を行うことにした.
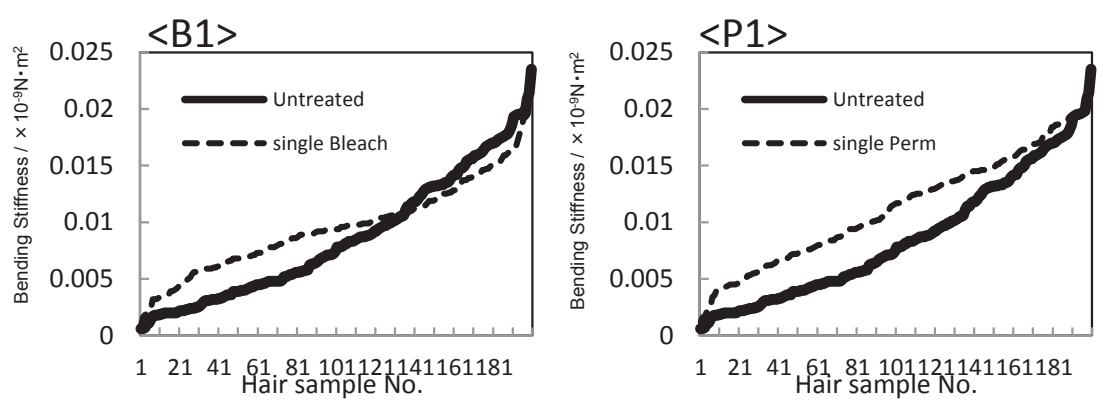

$<$ B2>
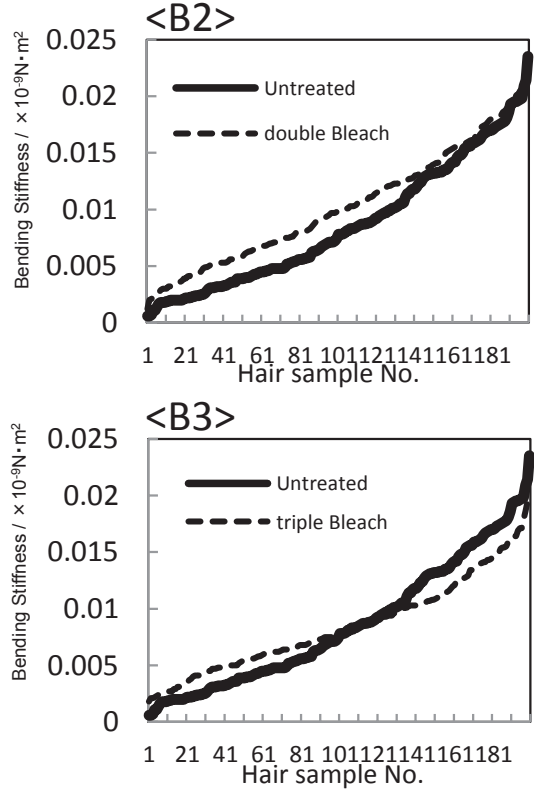

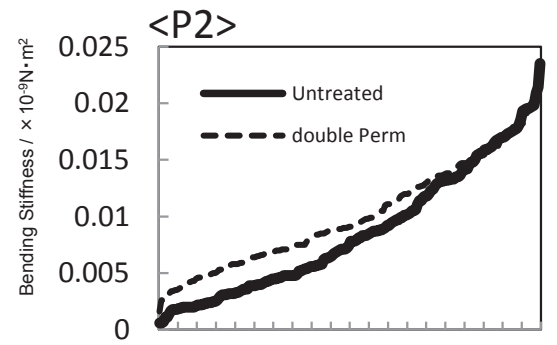

1214161.81101121141161181

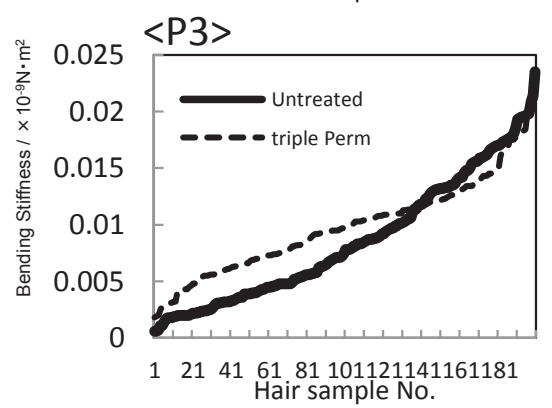

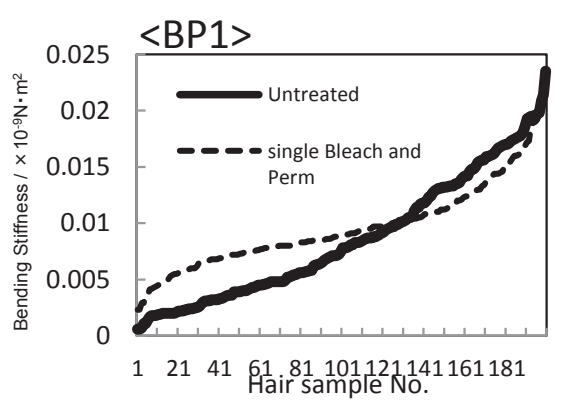

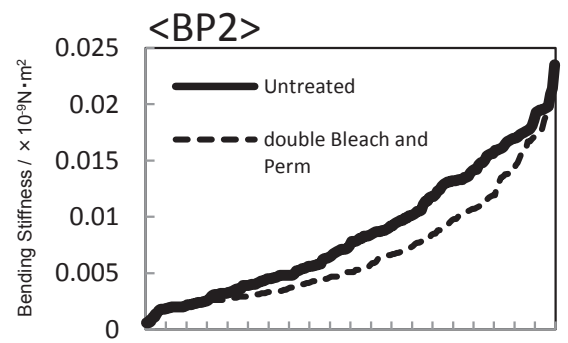

121416181101121141161181

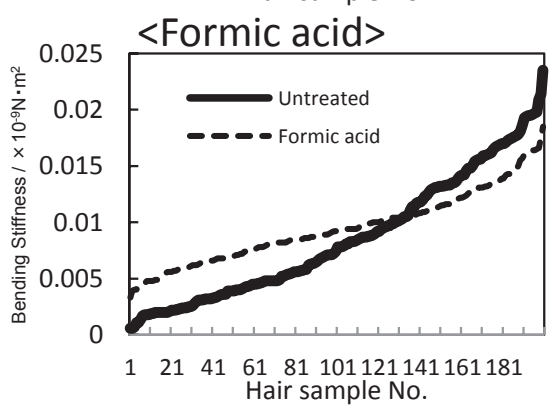

Fig. 7 Bending stiffness distribution curves of untreated hair and each chemical damaged hair. 


\subsection{3曲げ剛性分布曲線の各領域の平均値と官能 評価との相関算出}

我々は改質処理毛束の曲げ剛性分布曲線をある領域に区切 り, その中に含まれる值の平均值を求め, その值と官能評価 との相関について検討することにした，まず，各改質処理 毛束の曲げ剛性分布曲線を曲げ剛性 B 值の低い方から 10 本 ずつ 20 の区分に細分割し, それぞれの区分毎の平均值を算 出した。 続いて, 求めた平均值と各改質処理毛束で実施し た官能評価 1 回目および 2 回目との相関関係を, IBM SPSS Statistics Ver.23 を用いて Pearsonの相関係数を算出し Table 2 に示した，その結果，曲げ剛性值の低い側では各官能評価と 低い負の相関関係であり, 曲げ剛性が中程度では弱〜中程度 の正の相関関係となり, 曲げ剛性值が非常に高い区分では高 い正の相関関係が認められた。最も各官能評価との相関が高 いのは, 曲げ剛性分布曲線の上位 $91 \%-95 \%$ の区分の平均 值であり，相関係数は 0.7 以上で有意傾向以上であった。 そ の次に相関が高い区分は, 官能評価 1 回目と 2 回目で異なり, 官能評価 1 回目では上位 $96 \%$ - $100 \%$ の区分の曲げ剛性平均 值と, 官能評価 2 回目では上位 $86 \%-90 \%$ の区分の曲げ剛 性平均值との間に比較的高い相関が見られた。

次に，曲げ剛性分布曲線の剛性值の上位から $5 \%, 10 \%$, $15 \%, 20 \%, 25 \%, 30 \%, 35 \%, 40 \%$, および $100 \%$ を評 価区分として設定し, その平均值と官能評価との相関係数を 同様に算出した (Table 3). その結果, 官能評価 1 回目では曲 げ剛性分布曲線の上位 $15 \%(86 \%-100 \%)$ の平均值が最も 官能評価と高い相関を示し, Table 2 で示した 10 本ずつ設定 した区分の平均值よりも高い相関係数が得られた。官能評価 2 回目では, 上位 $40 \%(61 \%-100 \%)$ まで高い相関を示した が，最も相関が高かったのは Table 2 で示した $91 \%$ - $95 \%$ の

Table 2 Correlation coefficient between the bending stiffness average of "each 5\% section" and each sensory evaluation average.

\begin{tabular}{|c|c|c|c|c|}
\hline & \multicolumn{2}{|c|}{ 1st sensory evaluation test } & \multicolumn{2}{|c|}{ 2nd sensory evaluation test } \\
\hline & $\begin{array}{l}\text { earson product-moment } \\
\text { correlation coefficient }\end{array}$ & $P$ value & $\begin{array}{c}\text { Pearson product-moment } \\
\text { correlation coefficient }\end{array}$ & $P$ value \\
\hline section (1\%-5\%) & -.381 & .399 & -.119 & .799 \\
\hline section $(6 \%-10 \%)$ & -.202 & .664 & .246 & .596 \\
\hline section $(11 \%-15 \%)$ & -.076 & .871 & .260 & .574 \\
\hline section $(16 \%-20 \%)$ & .007 & .988 & .328 & .472 \\
\hline section $(21 \%-25 \%)$ & .023 & .962 & .399 & .375 \\
\hline section $(26 \%-30 \%)$ & .077 & .870 & .429 & 337 \\
\hline section $(31 \%-35 \%)$ & .091 & .847 & .439 & .325 \\
\hline section (36\%-40\%) & .140 & .764 & .499 & .254 \\
\hline section $(41 \%-45 \%)$ & .217 & .640 & .559 & .192 \\
\hline section ( $46 \%-50 \%)$ & .306 & .504 & .633 & .127 \\
\hline section $(51 \%-55 \%)$ & .339 & .458 & .700 & .080 \\
\hline section $(56 \%-60 \%)$ & .390 & .387 & .740 & .057 \\
\hline section $(61 \%-65 \%)$ & .466 & .292 & .743 & .056 \\
\hline section $(66 \%-70 \%)$ & .504 & .249 & $.761^{*}$ & .047 \\
\hline section $(71 \%-75 \%)$ & .515 & .237 & $.762^{*}$ & .046 \\
\hline section $(76 \%-80 \%)$ & .597 & .157 & $.781^{*}$ & .038 \\
\hline section $(81 \%-85 \%)$ & .603 & .152 & .741 & .057 \\
\hline section ( $86 \%-90 \%)$ & .675 & .096 & $.781^{*}$ & .038 \\
\hline section (91\%-95\%) & .706 & .076 & $.866^{*}$ & .012 \\
\hline section $(96 \%-100 \%)$ & .678 & .094 & .667 & .101 \\
\hline
\end{tabular}

区分であった。したがって, Table 2, Table 3 の結果を合わせ ると, 毛束のハリコシ感の客観的な評価方法としては, 毛束 から無作為に選び出した毛髪で曲げ剛性分布曲線を求め, そ の上位 $10 \%$ ～15\%までの曲げ剛性分布曲線の平均值を用い る方法が最も適していると考えられた。

Table 3 Pearson product-moment correlation coefficient between the bending stiffness average of each "up to $100 \%$ section" and each sensory evaluation average.

\begin{tabular}{|c|c|c|c|c|}
\hline & \multicolumn{2}{|c|}{ 1st sensory evaluation test } & \multicolumn{2}{|c|}{ 2nd sensory evaluation test } \\
\hline & $\begin{array}{l}\text { earson product-moment } \\
\text { correlation coefficient }\end{array}$ & $P$ value & $\begin{array}{c}\text { Pearson product-moment } \\
\text { correlation coefficient }\end{array}$ & $P$ value \\
\hline section $(1 \%-100 \%)$ & 376 & 406 & 694 & .083 \\
\hline section $(61 \%-100 \%)$ & .664 & .104 & 824 & .023 \\
\hline section $(66 \%-100 \%)$ & .671 & .099 & 823 & .023 \\
\hline section $(71 \%-100 \%)$ & .679 & .093 & 813 & .026 \\
\hline section $(76 \%-100 \%)$ & .701 & .079 & .816 & .025 \\
\hline section $(81 \%-100 \%)$ & .712 & .073 & 814 & .026 \\
\hline section ( $86 \%-100 \%)$ & .718 & .069 & 807 & .028 \\
\hline section $(91 \%-100 \%)$ & .709 & .074 & 803 & .030 \\
\hline section (96\%-100\%) & .678 & .094 & 667 & 101 \\
\hline
\end{tabular}

以上のように, 改質処理毛束の曲げ剛性分布曲線をある領 域に区切り, その中に含まれる值の平均值を求め, その值と 官能評価との相関について統計的に解析した結果, 曲げ剛性 分布曲線の高剛性域 $10 \%$ ～15\%に含まれるそれぞれの剛性 值の平均值とハリコシの官能評価との間に高い相関が得られ たことから, 少なくとも毛束のハリコシ感を感じ取る情報の 一つとして曲け剛性分布曲線の高剛性域 $10 \%$ ～15\%に含ま れる毛髪の曲げ剛性值（曲げ硬さ）が関与していることが明 らかとなった。

\section{4 .4 毛髪のサンプリング数と曲げ剛性平均值の 算出区分の検討}

最後に, 曲げ剛性分布曲線を描く場合, 測定する毛髪のサ ンプリング数で官能評価との相関が変化する可能性が考えら れたため, どの程度のサンプリング数で相関值がどの程度変 化するかを確認することにした，確認は，すでに測定済みの 200 本のデー夕をそれぞれ 100 本ずつおよび 50 本ずつで測 定したと仮定し， 200 本測定した場合のデータと比較するこ とにより行った。 100 本ずつに分ける方法として, 測定した 200 本のデータを測定順に並べ，奇数回に測定した 100 本と， 偶数回に測定した 100 本に分けた. 50 本ずつ分ける方法と して，200本のデー夕を測定した順に並べ，4で割って余り 1 〜 となる回に測定した 50 本ずつに分けた。 それぞれ分 けた毛髪の本数毎に曲げ剛性分布曲線を作成し，上位から 5 $\%, 10 \%, 15 \%, 20 \%, 25 \%, 30 \%$ の区分で平均值を算出 し, 官能評価 1 回目と算出した相関係数を Table 4 に, 2 回目 と算出した相関係数を Table 5 に示した。 これらの相関係数 を Table 2 およびTable 3 に示した 200 本のデータと比較した.

Table 4 の官能評価 1 回目と各領域の曲げ剛性值の平均との 相関係数より, 測定本数を 100 本に減らしても相関係数は上 
Table 4 Pearson product-moment correlation coefficient between the first sensory evaluation test and the bending stiffness average of each number hair's each section.

\begin{tabular}{lccccccc}
\hline & top $5 \%$ & top $10 \%$ & top $15 \%$ & top $20 \%$ & top $25 \%$ & top $30 \%$ & \multirow{2}{*}{ all ave. } \\
& ave. & ave. & ave. & ave. & ave. & ave. & all \\
\hline 200 hairs $(1-200)$ & .678 & .709 & .718 & .712 & .701 & .679 & .376 \\
\hline 100 hairs $($ odd) & .746 & .752 & .738 & .744 & .745 & .734 & .257 \\
100 hairs $($ even $)$ & .631 & .720 & .725 & .686 & .651 & .619 & .451 \\
\hline 50 hairs $(\div 4$ remainder 1$)$ & & $.855^{*}$ & & .707 & & .607 & .204 \\
50 hairs $(\div 4$ remainder 2$)$ & & .739 & & .715 & & .659 & .498 \\
50 hairs $(\div 4$ remainder 3$)$ & & .617 & & .687 & & .743 & .306 \\
50 hairs $(\div 4$ remainder 0$)$ & & .637 & & .557 & & .514 & .365 \\
\hline & & & & & & & $*$ * P $<0.05$
\end{tabular}

Table 5 Pearson product-moment correlation coefficient between the second sensory evaluation test and the bending stiffness average of each number hair's each section.

\begin{tabular}{lccccccc}
\hline & top $5 \%$ & top $10 \%$ & top $15 \%$ & top $20 \%$ & top $25 \%$ & top $30 \%$ & \multirow{2}{*}{ all ave. } \\
& ave. & ave. & ave. & ave. & ave. & ave. & \\
\hline 200 hairs $(1-200)$ & .667 & $.803^{*}$ & $.807^{*}$ & $.814^{*}$ & $.816^{*}$ & $.813^{*}$ & .694 \\
\hline 100 hairs (odd) & .710 & $.902^{* *}$ & $.951^{* *}$ & $.949^{* *}$ & $.929^{* *}$ & $.902^{* *}$ & .607 \\
100 hairs (even) & .622 & .700 & .710 & .706 & .708 & .712 & .728 \\
\hline 50 hairs $(\div 4$ remainder 1$)$ & & $.839^{*}$ & & $.809^{*}$ & & .744 & .559 \\
50 hairs $(\div 4$ remainder 2) & & .601 & & .633 & & .662 & .735 \\
50 hairs $(\div 4$ remainder 3$)$ & & .735 & & $.862^{*}$ & & $.898^{* *}$ & .646 \\
50hairs $(\div 4$ remainder 0$)$ & & .740 & & .685 & & .703 & .686 \\
\hline & & & & & & $*$ *: P $<0.05 * *:$ P $<0.01$
\end{tabular}

位 $10 \%$ ，上位 $15 \%$ で高く，200 本測定した場合と同等の高 い相関係数が得られた。しかし 50 本の場合は相関係数が 0.7 以下に低下する場合も見られた。なお，50本の場合はデー 夕数が少ないため，上位 $5 \%$, $15 \%$ は設定できなかった。官 能評価 2 回目と各領域の曲げ剛性值の平均との相関係数を示 した Table 5 においても, 測定本数を 100 本に減らすとやや 相関係数はばらつくものの，200 本測定した場合と同等の高 い相関係数が得られた。 50 本の場合は，一部で低い相関係 数となった

以上のように, 測定毛髪本数が 100 本以上であれば得られ た曲げ剛性分布曲線の高剛性域（上位 $15 \%$ 以上）の平均剛 性值と官能評価との間に高い相関係数が得られたことから, 数種の毛束間のハリコシ感の比較において，それぞれの毛束 より採取した毛髪 100 本以上の曲げ剛性值より求めた曲げ剛 性分布曲線の高剛性域の平均剛性值を比較することによっ て，ハリコシ感の差を予想できるものと考えられた。

\subsection{5毛束のハリコシ感覚特性と構成毛髮の曲げ 剛性特性との関係}

毛束のハリコシ感は, 毛束を触れた際に加える作用力に応 じた変形に対する毛束全体で発生する反作用力を，指腹に内 包された複数の皮膚感覚受容器が反応することによって得ら れる硬さ・柔らかさの感覚によるものである。この場合の反 作用力は, 主に毛束構成毛髪個々で発生する歪応力と構成毛 髪間の摩擦抵抗力によるものである。したがって, 本実験で の曲げ剛性分布曲線は毛束変形時に生じる毛髪間の摩擦抵抗
力の影響が含まれない毛束の曲げ応力を示したものとなり， 毛束を構成する毛髪の曲げ剛性がハリコシ感を知覚する因子 であることを示すものである。しかし，トリートメント処理 をした毛束の「やわらかさ」と曲げ剛性 B 值との関係を検討 した河野ら [14]は，トリートメント処理により「やわらか さ」の評価が良くなり, B 值との間に負の相関が得られたこ とを報告している。この場合の毛束の曲げ剛性 B 值は, $2 \mathrm{~cm}$ の幅に 200 本毛髪を並べた試料を曲げた場合の曲げ剛性 B 值 であり，個々の構成毛髪の曲げ剛性のみを評価しているので はなく，毛髪間相互作用力および毛髪表面特性としての「な めらかさ，さらさら」感等の影響が優勢となったためと考え られる。このことを考え合わせると, 毛髪間の摩擦抵抗力等 の毛髪表面特性で発生する反作用力がある限られた範囲内に ある場合に, 個々の毛髪の曲げ剛性がハリコシ感に影響をお よぼし, 毛束のハリコシ感の違いが知覚されると考えられる。 したがって，今回の実験結果は，構成毛髪の曲げ剛性が知覚 に影響をおよぼした例の一つであると言える。

今回は, 毛束のハリコシ感が毛束構成毛髪の中で高剛性域 の毛髪の曲け剛性值に影響されていたが, このことは, 羊毛 製品の「ちくちく感」に関する研究 $[21,22]$ や対象物の力 学特性と硬さ知覚との関係に着目した研究報告 $[23,24]$ か ら，次のように考えることができる。羊毛製品の「ちくちく 感」に関するこれまでの研究所見 [21] としては，「ちくちく 感」は皮膚の痛覚受容体が活性化して生じるが, この刺激が 布に $5 \%$ 以上混入する直径 $30 \mu \mathrm{m}$ 以上の繊維によるものであ り，皮膚接触面が $5 \mathrm{~cm}^{2}$ 以上であること，などであった。そ の後, 「ちくちく感」は羊毛繊維に限定されるものでなく他 の繊維素材でも起こり得るものであり, 皮膚に触れる布の繊 維直径が $32 \mu \mathrm{m}$ 以上の割合が $5.2 \%$ 以上では，大人はほぼ全 員が「不快」と評価すると報告されている [22]。このことは， 太い繊維はヤング率が同じであれば曲げ剛性は高くなること から，ある一定以上の剛性值を呈する繊維が $5.2 \%$ 以上含ま れると皮膚の痛覚受容体が活性化すると言い換えることがで きる，すなわち，ちくちく感においては閯值が存在し，ある 一定值以上の刺激となった場合に知覚されることを示唆して いる.

また，高瀬ら [23] は，ヤング率の異なる弾性物体の提示 刺激と硬さ感覚特性におよぼす指腹の変形との関係について 検討を行い，対象物の硬さに応じた指腹自体の変形の違いが 硬さ感覚に影響をおよぼしており，硬く感じるほどその変形 度合が高いことを示した。また，別に上層と下層で硬さの異 なる弾性対象物を人差し指で押し込む際の硬さ感覚を心理物 理学的手法に評価した結果, 下層の硬さ（ヤング率）によら ず，指先が直接触れる上層の硬さ（ヤング率）が優位である こと，さらには，上層の硬さがある限られた範囲内にある場 合には, 指先が直接触れない下層の硬さの違いが硬さ感覚特 性に影響をおよぼし，わずかな硬さの違いを知覚しやすくな る可能性を見いだしている [24]。これらの知見に基づけば, 毛束を指先で触り感触を確かめる際，わずかな曲げ硬さの違 いが指腹の変形を誘い一定以上の変形において感覚受容体が 活性化されると考えることができる。ささらに，2層からなる 
弾性対象物モデルをさまざまな曲げ剛性を有する毛髪の集合 体である毛束に当てはめると, 毛束は低・中曲げ剛性層と高 曲げ剛性層からなる弾性対象物と捉えることができ, 下層と しての役割を果たす低・中剛性層の硬さの違いが硬さ感覚特 性に影響をおよぼし, 高剛性層のわずかな剛性の違いが知覚 されやすくなったと考えることができる。

以上のことを総合すると, 今回得られたハリコシ感が高剛 性域（上位 $15 \%$ ）の毛髪の平均剛性值と高い相関があった ということは，「ハリコシ感を感じるには，ある一定值以上 の刺激を与える毛髪がある一定以上含まれる必要があり，そ れが曲げ剛性において高剛性域の毛髪である。 そして, その わずかな剛性值（刺激）の違いが中・低剛性值の毛髪の存在 によってより鋭敏に知覚された」ことによると推察すること ができる。

\section{4. 結 言}

髪の毛のハリコシ感が加齢や化学的ダメージによって変化 することから, 加齢の指標の一つである白髪や, ブリーチや パーマおよび濃ギ酸による化学処理が, 髪の毛のハリコシ感 にどのように影響をおよぼすかについて官能評価を実施する とともに，それぞれの毛束を構成している毛髪の曲げ剛性分 布曲線との関係を明らかにすることを目的として，検討を 行った。 その結果, 白髪毛束と黒髪毛束の官能評価では, 両 者間でハリコシ感に差異が認められるが，個人によりその相 対関係は異なることから, 白髪が加齢によるハリコシ感の低 下の原因であるとは言えないことがわかった。その一方で, 毛束間にハリコシ感の差があるとき, 曲げ剛性分布曲線での 高剛性域の分布の違いがあることが見出された。さらに，日 常の化学処理であるブリーチ処理, パーマ処理, ブリーチ। パーマ処理のハリコシ感におよぼす影響では, 処理回数に よって異なっているものの, ハリコシ感は未処理毛束と同等 かやや強くなる傾向が認められることがわかった. 一方, 細 胞膜複合体が主に改質されている濃ギ酸処理毛束では有意に ハリコシ感が低下することがわかった。これらの結果を踏ま え, それぞれの曲げ剛性分布曲線を精査した結果, ブリーチ / パーマ 2 回処理毛束を除き, いずれの処理毛束も低剛性域 および中剛性域の分布が有意に高くなり，高剛性域での分布 は処理により異なった。そこで，ハリコシ感として感じ取る 情報の一部が曲げ剛性分布曲線の中に含まれるものとして, 改質処理毛束での官能評価と曲げ剛性分布曲線に含まれる情 報との関係をより定量的に解析した。解析は曲げ剛性分布曲 線をある領域に区切り剛性值の平均值を求め, 官能評価との 相関をPearsonの相関係数より判定した. その結果, 分布曲 線の剛性值上位 $10 \%$ ～15\%が最も高い相関を示すことが見 いだされた。このことから, 髪の毛のハリコシ感は単純に曲 げ硬さのみで判断しているのではないであろうが, 対象とす る毛束より 100 本以上の毛髪を任意に選び, 曲げ剛性分布曲 線の上位 $15 \%$ の剛性值の平均值を用いることで, 多様な髪 の毛のハリコシ感を客観的に評価できるものと考えられた。

\section{謝 辞}

本検討中の官能評価と曲げ剛性の相関係数の算出および, 必要本数の算出に際して用いた統計学的な考察に関しまして は, 大阪大学大学院基礎工学研究科の狩野 裕教授に御監修 いただきました。この場を借りて，深く感謝の意を表します。

\section{References}

[1] Kaname K, Moriwaki K (2010) J Jpn Hair Sci Assoc, 2, 1418

[2] Watanabe S, Yokomaku A (1999) FREGRANCE J, 9, 36-41

[3] Fukuhara M (2010) FREGRANCE J, 6, 59-64

[4] Furukawa T (2014) "Kannou hyouka katuyou nouhau kankaku no teiryouka · suuchika syuhou” p474, Gijyutsu Jyouhou Kyoukai, Tokyo

[5] Kuwabara S, Mori M, Ueda S, Joko K (2015) J Text Eng, 4, $41-47$

[6] Soma T, Iwabuchi T (2009) J Jpn Hair Sci Assoc, 2, 28-33

[7] Miyazawa K, Kaneda I, Iizuka N, Yanaki T, Uemura M (2003) J Soc Cosmet Chem Jpn, 4, 301-308

[8] Sidney B, H, Nigel J.P.W (2001) J Cos Sci, 5, 330-331

[9] Iwata H (1993) FREGRANCE J, 6, 63-72

[10] J. G. Gould, R. Sneath (1985) J Soc Cosmet Chem, 36, 53-59

[11] Arai K, (2003) "Saishin no mouhatsu kagaku”, p72, Fureguransu Ja-nal Sha, Tokyo

[12] J. D. Leeder, D. G. Bishop, L.N.Jones (1983) Text Res J, 53, 402-407

[13] Amaya M, Sawada M, Yoshida H, Joko K (2013) Sen'i Gakkaishi, 69, 132-140

[14] Kono H, Suganuma K, Furukawa T(1999) J Soc Cosmet Chem Jpn, 33, 4, 377-385

[15] C. R. Robbins (2012) "Chemical and Physical Behavior of Human Hair" $5^{\text {th }}$ Edition, Springer, Heidelberg

[16] Takizawa T, Takizawa T, Arai S, Osumi M, Saito T (1998), Anat Rec, 251,406-413

[17] Kuzuhara A (2007) Biopolym, 85, 274-283

[18] Ogawa S, Takeda Y, Kaneyama K, Komoto T (2008) Sen'i Gakkaishi, 64 352-357.

[19] Inoue T, Takehara K, Kizawa K, Fujimori T, Takeuchi A, Uesugi K, Suzuki Y (2012) J Soc Cosmet Chem Jpn, 46, 101106

[20] Nawa T (2013) Doctor thesis, Tohoku University

[21] R. K. Garnsworthy, R. L.Gully, P. Kenins, R. J.Mayfield, R. A. Westernman (1988) J Neurophysiol, 59, 1083-1097

[22] G. R. S.Naylor, D. G.Phillips, C. J.Veitch, M.Dolling, and D. J. Marland (1997) Text Res J, 67, 288-295

[23] Takase S, Doi K, Fujimoto H (2009) T JSKE, 8, 1105-1111

[24] Takase S (2009) Ningen Kagaku Kenkyu, 22, (Supplement), 77 